\title{
A Case of XYY Down's Syndrome Confirmed by Autoradiography
}

\author{
RENATA LAXOVA,* JANET A. McKEOWN, P. SALDANA, and J. A. D. TIMOTHY \\ From Kennedy-Galton Centre, Harperbury Hospital, near St Albans, Herts.
}

Double aneuploidy in Down's syndrome was first described by Ford et al (1959) in a patient showing both Down's and Klinefelter's syndromes. Since then, at least 33 further cases of Down's syndrome have been described with additional aneuploidy (see Table). Approximately half of these are associated with autosomal aneuploidy, the remainder with abnormalities of the sex chromosomes among which are three definite examples of Down's syndrome with an additional $\mathrm{Y}$ chromosome. The first, a 9-year-old boy, was reported by Verresen and van den Berghe (1965); the second, a newborn infant, who died aged 7 weeks as a result of severe cardiac malformation, was reported by Uchida, Ray, and Duncan (1966). The third was men-

Received 26 May 1970.

* In receipt of a grant from the Medical Research Council. tioned in a personal communication by D. S. Borgaonkar, S. P. Borkowf, V. A. McKusick, and E. Mules (1969). Moreover, the small acrocentrics, reported by Hall (1963), in two unrelated males with Down's syndrome and in their phenotypically normal fathers, may have been $\mathrm{Y}$ chromosomes rather than $\mathrm{Ph}_{1}$ chromosomes.

The present report records an example of an extra $\mathrm{Y}$ chromosome in a case of Down's syndrome in which it was possible to confirm the identity of the additional chromosome by autoradiography.

\section{Case History}

The patient, a male, born in April 1969 was the result of a first, uneventful pregnancy and vertex delivery; the ages of the mother and father at his birth were 24 years and 27 years, respectively. Birthweight was $3034 \mathrm{~g}$ but the length was not determined. The family history was

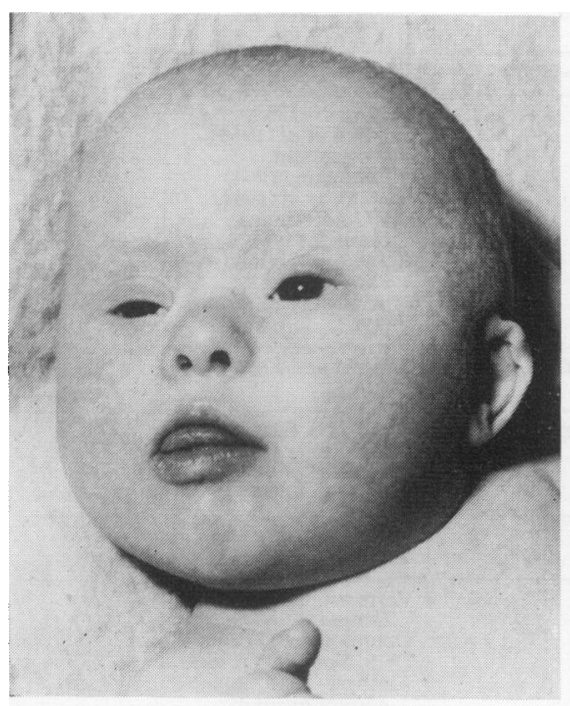

(a)

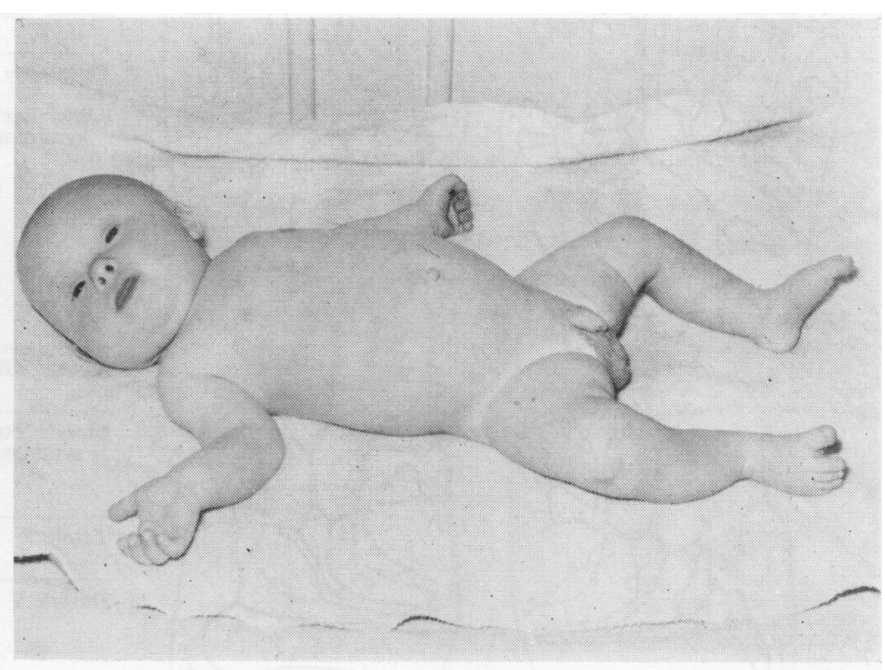

(b)

FIg. 1. Patient at 3 months of age. 
unremarkable; a paternal second cousin is retarded but not a mongol. At birth the propositus was slightly jaundiced but not cyanosed. On the fourth day the parents were told of the diagnosis of Down's syndrome and, later, referred to the Kennedy-Galton Centre for advice.

The baby was seen in July at the age of 3 months. There was no record of illness and, apart from slight feeding difficulties, he was gaining weight satisfactorily. At 2 months he had been admitted to a near-by hospital for permanent care.

At the time of examination, the baby was well nourished, eutrophic, and readily recognizable as a typical case of Down's syndrome (Fig. 1). His weight was $5580 \mathrm{~g}$, length $59.5 \mathrm{~cm}$, head length, breadth, and circumference were 134,110 , and $386 \mathrm{~mm}$ respectively, with a cephalic index of 0.82 . A third fontanelle was present in a wide sagittal suture, the anterior fontanelle measured $3 \times 3 \mathrm{~cm}$. Further features of Down's syndrome included oblique palpebral fissures, epicanthic folds, Brushfield's spots, a high arched palate, protruding tongue, small asymmetrical ear lobes with angular overlapping helices, incurved fifth fingers, visible spaces between first and second toes, hypotonic musculature, dry marmorated skin. There was no heart defect and no apparent abnormality of the external genitalia: both testes were descended. Head control was absent; the baby did not smile but was able to follow objects with his eyes.

He was seen again at 12 months, during a period of convalescence after a severe intercurrent infection (bronchopneumonia sin.). His weight was $7031 \mathrm{~g}$ (hav-

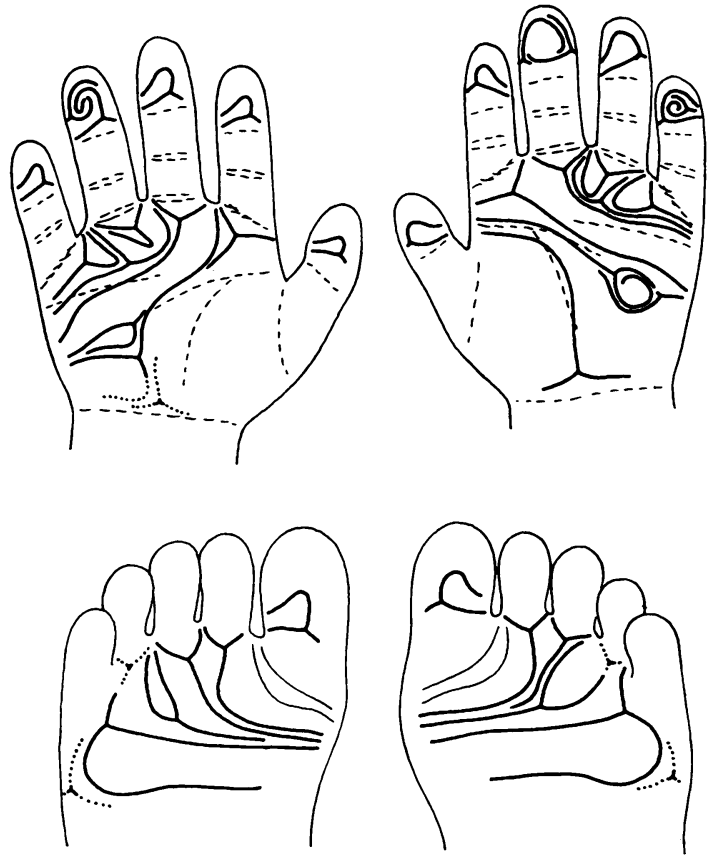

FIG. 2. Main dermatoglyphic lines on palms and soles of the patient. ing been as low as $5220 \mathrm{~g}$ at 11 months), the length was $68.5 \mathrm{~cm}$, head length, breadth, and circumference were 136,117 , and $407 \mathrm{~mm}$ respectively, cephalic index 0.86 , the chest circumference $381 \mathrm{~mm}$. He had acquired head control, could smile and laugh aloud, grasp and play with toys. He could not sit up unaided and could

TABLE

EXAMPLES OF DOWN'S SYNDROME WITH ADDITIONAL ANEUPLOIDY

\begin{tabular}{|c|c|c|c|}
\hline $\begin{array}{l}\text { Additional } \\
\text { Aneuploidy }\end{array}$ & $\begin{array}{l}\text { No. of } \\
\text { Cases }\end{array}$ & Authors & $\begin{array}{l}\text { Symptoms } \\
\text { of Down's } \\
\text { Syndrome } \\
\text { Prevailing }\end{array}$ \\
\hline $\begin{array}{l}\text { Translocation } \\
(13-15):(13-15)\end{array}$ & 7 & $\begin{array}{l}\text { T. W. J. Hustinx (1963, } \\
\text { personal } \\
\text { communication) } \\
\text { Zergollern et al (1964) } \\
\text { Richards, Stewart, and } \\
\text { Sylvester (1965) } \\
\text { Marsden et al (1966) } \\
\text { Orye and Delire (1967) } \\
\text { Ridler et al (1969) } \\
\text { Ridler et al (1969) }\end{array}$ & $\begin{array}{l}+ \\
+ \\
+ \\
+ \\
+ \\
+ \\
? \\
+ \\
+\end{array}$ \\
\hline $\begin{array}{l}\text { Translocation } \\
(13-15):(19-20)\end{array}$ & 1 & $\begin{array}{l}\text { Gripenberg and } \\
\text { Airaksinen (1964) }\end{array}$ & + \\
\hline Trisomy 13-15 & 1 & $\begin{array}{l}\text { Becker, Burke, and } \\
\text { Albert (1963) }\end{array}$ & + \\
\hline $\begin{array}{l}\text { Mosaic trisomy } \\
13-15\end{array}$ & 2 & $\begin{array}{l}\text { Smith, Lips, and } \\
\text { Howard (1965) } \\
\text { Porter, Petersen, and } \\
\text { Browne (1969) }\end{array}$ & + \\
\hline Trisomy 18 & 1 & Gagnon et al (1961) & - \\
\hline Mosaic trisomy 18 & 4 & $\begin{array}{l}\text { Hsu et al (1965) } \\
\text { Marks, Wiggins, and } \\
\text { Spector (1967) } \\
\text { Zellweger and Abbo } \\
\text { (1967) } \\
\text { Glogowska (1969) }\end{array}$ & $\begin{array}{l}- \\
+ \\
+ \\
+\end{array}$ \\
\hline $\begin{array}{l}\text { Mosaic trisomy } \\
19-20\end{array}$ & 1 & $\begin{array}{l}\text { Gustavson and Ek } \\
\text { (1961) }\end{array}$ & + \\
\hline Tetrasomy $21-22$ & 1 & Townes (1968) & + \\
\hline $\begin{array}{r}\text { Klinefelter's } \\
\text { syndrome }\end{array}$ & 7 & $\begin{array}{l}\text { Ford et al (1959) } \\
\text { Lanman et al (1960) } \\
\text { Forssman and } \\
\text { Lehmann (1962) } \\
\text { Hustinx et al (1961) } \\
\text { van Gelderen and } \\
\text { Hustinx (1961) } \\
\text { Hamerton, Jagiello, and } \\
\text { Kirman (1962) } \\
\text { Milcou and Maicanesco } \\
\text { (1963) }\end{array}$ & $\begin{array}{l}+ \\
+ \\
+ \\
+ \\
+ \\
+ \\
+\end{array}$ \\
\hline Mosaic Klinefelter & 1 & $\begin{array}{l}\text { Punnett and Di George } \\
(1967)\end{array}$ & + \\
\hline $\begin{array}{l}\text { Mosaic Turner's } \\
\text { syndrome }\end{array}$ & 2 & $\begin{array}{l}\text { van Wijck, Blakenborg, } \\
\text { and Stolte (1964) } \\
\text { Zergollern and } \\
\text { Hoefnagel (1964) }\end{array}$ & $\begin{array}{l}+ \\
+\end{array}$ \\
\hline Triple X & 2 & $\begin{array}{l}\text { Day et al (1963) } \\
\text { Yunis et al (1964) }\end{array}$ & $\begin{array}{l}+ \\
+\end{array}$ \\
\hline Double Y & $\begin{array}{c}4 \\
(?+2)\end{array}$ & $\begin{array}{l}\text { Verresen and van den } \\
\text { Berghe (1965) } \\
\text { Uchida et al (1966) } \\
\text { D. S. Borgaonkar and } \\
\text { others (1969, personal } \\
\text { communication) } \\
\text { present case (1970) } \\
\text { Hall (1963) (? } 2 \text { cases) }\end{array}$ & $\begin{array}{l}+ \\
+ \\
+ \\
+ \\
+\end{array}$ \\
\hline
\end{tabular}




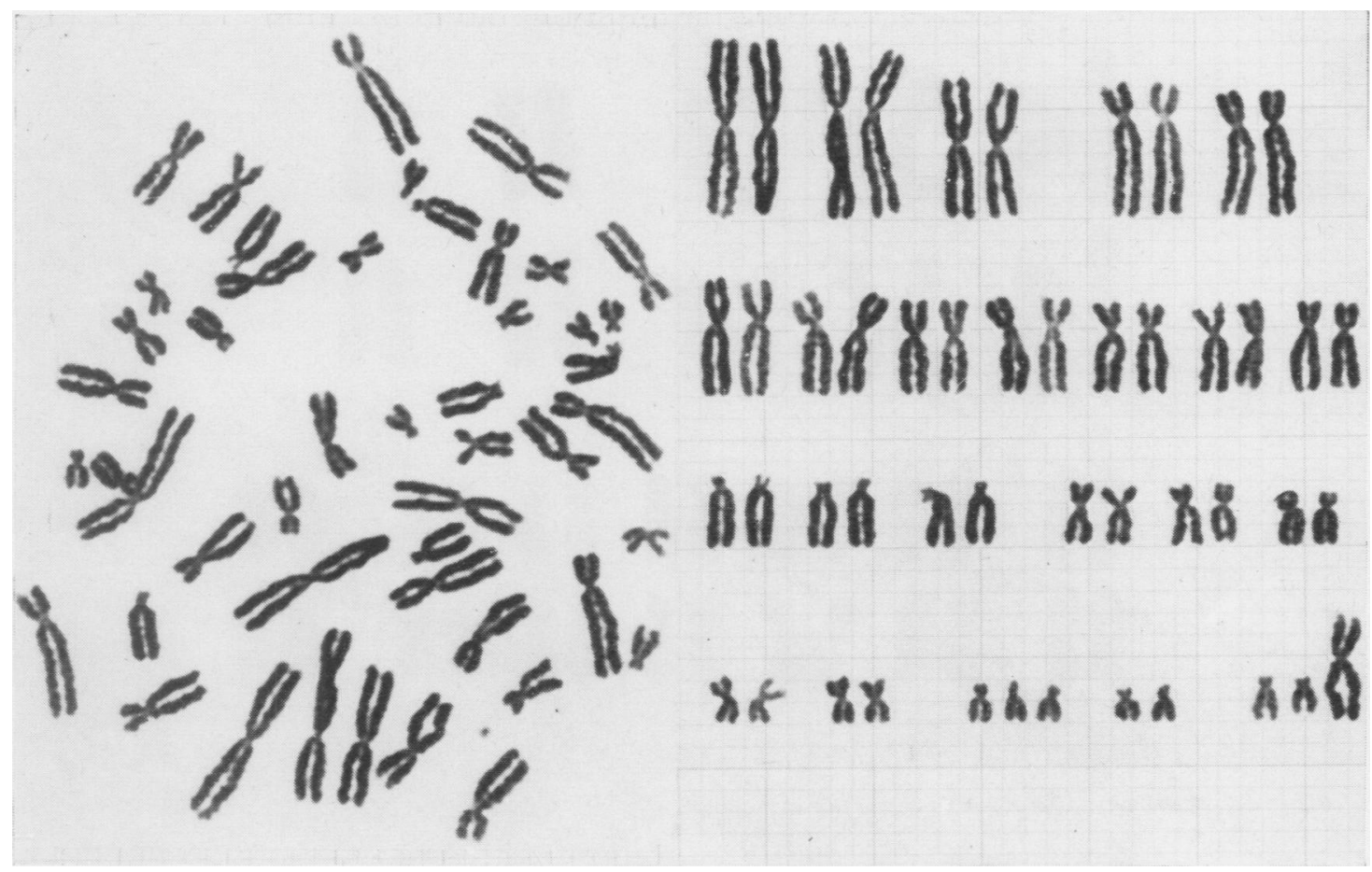

FIG. 3. Karyotype of leucocyte culture from the patient showing 48 chromosomes with trisomy G and XYY.

not turn over. His general physical appearance was unchanged and was characteristic of a patient with Down's syndrome.

The dermatoglyphic main lines of the patient's hands and feet are illustrated in Fig. 2. There is no fourfinger crease on either palm, but the radial loop on the right fourth finger, bilateral distal palmar triradii (ie, wide maximal atd angles, right $82^{\circ}$, left $87^{\circ}$ ) and absence of pattern in both hallucal areas are all features characteristic of Down's syndrome (Penrose and Smith, 1966). The total ridge count, which is usually low in both Down's syndrome and in patients with supernumerary sex chromosomes (Penrose, 1967; Penrose and Loesch, 1967 ), is 165 (6 ulnar loops, 3 whorls, 1 radial loop) in this case, which is above that of the male average (145). The father's total ridge count is 180 and the mother's 77 .

The chromosomes of the patient were analysed in preparations from leucocyte and fibroblast cultures. From leucocyte preparations only the parents were both found to have normal karyotypes. In the propositus, a consistent diploid number of 48 chromosomes was found in both tissues. In all cells examined, there appeared to be G-trisomy, together with an additional small acrocentric chromosome showing the characteristic morphology of a Y. Autoradiographically, this chromosome showed a labelling pattern consistent with that of a late replicating $\mathrm{Y}$. There was no suggestion of mosaicism (see Figs. 3 and 4).

\section{Discussion}

Autoradiography seems to be an adequate way of confirming the identity of the extra chromosome as a Y because there are two very similar, late replicating chromosomes. Thus, any ambiguity which may have arisen in previous cases (Hall, 1963) is ruled out.

However, the significance of the additional $\mathrm{Y}$ chromosome is, as yet, insufficiently understood. An XYY sex chromosome complement, without any abnormal phenotypical effect, may be found in the general population (Forssman, Akesson, and Wallin, 1968). It may, on the other hand, be associated with the typical combination of tall stature and psychopathic behaviour (Price and Whatmore, 1967; Welch, Borgaonkar, and Herr, 1967). Alternatively, YY aneuploidy may be discovered because cytogenetical studies are prompted by the presence of a specific pathological condition, such as in the present case. The Table shows that the stigmata of Down's syndrome dominate the other symptoms.

The patient investigated by D. S. Borgaonkar and others (1969, personal communication) was found to be above the 90th centile for length at 6 
months of age. This finding cannot be confirmed by the present observation: the patient's length was in the 25th centile at 3 months and below the 3rd centile at 12 months of age. This seems more in accordance with the prevailing symptoms of Down's syndrome than those caused by the additional $Y$ chromosome which seem clinically unobtrusive, though they may be difficult to assess at the present age of the patient.

The chance that a patient with G-trisomy has additional aneuploidy is the product of the fre- quencies of each of these events in the population. If the incidence of Down's syndrome in this country is 1 in 700 (Penrose and Smith, 1966) and that of a male with an additional $\mathrm{Y}$ chromosome is approximately 1 in 700 males (Court Brown, 1968; Ratcliffe et al, 1970), then the incidence of YY males with Down's syndrome* is roughly the product of 1 in 700 and 1 in 700 , ie, 1 in about 500,000 male births.

* The fact that the sex ratio of Down's syndrome births sometimes indicates a predominance of males (Penrose and Smith, 1966) is negligible in a rough estimate such as the present one. 
If maternal age is taken into consideration, then the chance of this event occurring is more remote. A mother in the age-group 25-29 (as in the present case) has an absolute risk of 1 in 1200 (Penrose and Smith, 1966) of having a child with Down's syndrome. Thus, the risk among all births of a YY male mongol would be 1 in 840,000 .

The question naturally arises as to why so few patients with similar chromosomal complements have hitherto been reported. A plausible answer may be found if the chance of this event's occurring ( 1 in 700 males) is applied to the approximate number of mongols karyotyped in Britain. Ridler et al (1969), when estimating the incidence of $D / D$ translocations in British series of mongols, found a total of 2209 karyotyped mongols in 13 reported series. One would thus expect to find $1.5 \mathrm{YY}$ cases in such a series.

\section{Summary}

An extra $\mathrm{Y}$ chromosome is reported in a case of a male infant with Down's syndrome. The identity of the $\mathrm{Y}$ chromosomes is confirmed by autoradiography.

We are indebted to Professor L. S. Penrose for his helpful comments and encouragement in the preparation of this manuscript. We are also grateful to Mr A. J. Lee for his drawing of Figure 2.

\section{REFERENCES}

Becker, K. L., Burke, E. C., and Albert, A. (1963). Double autosomal trisomy (D trisomy plus mongolism). Proceedings of the Staff Meetings of the Mayo Clinic, 38, 242-248.

Court Brown, W. M. (1968). Males with an XYY sex chromosome complement. Fournal of Medical Genetics, 5, 341-359.

Day, R. W., Wright, S. W., Koons, A., and Quigley, M. (1963). XXX 21-trisomy and retinoblastoma. 'Lancet, 2, 154-155.

Ford, C. E., Jones, K. W., Miller, O. J., Mittwoch, U., Penrose, L. S., Ridler, M., and Shapiro, A. (1959). The chromosomes in a patient showing both mongolism and the Klinefelter syndrome. Lancet, 1, 709-710.

Forssman, H., Akesson, H. O., and Wallin, L. (1968). The YY syndrome. (Letter.) Lancet, $2,779$.

Forssman, H. and Lehmann, O. (1962). Chromosome studies in eleven families with mongolism in more than one member. Acta Paediatrica, 51, 180-188.

Gagnon, J., Katyk-Longtin, N., de Groot, J. A., and Barbeau, A. (1961). Double trisomie autosomique à 48 chromosomes $(21+18)$. Union Médicale du Canada, 90, 1220-1226.

Gelderen, H. H. van and Hustinx, T. W. J. (1961). Combinatie van het Klinefelter-syndroom met mongolisme. Nederlands Tijdschrift voor Geneeskunde, 105, 1925-1928.

Glogowska, I. (1969). Mozaika 47/48 u pacjenta z zespolem Downa. Neurologia i Neurochirurgia Polska, 3, 263-266.

Gripenberg, U. and Airaksinen, E. (1964). A D/F translocation in a case of regular trisomy 21 Down's syndrome. Cytogenetics, 3, 219-227.

Gustavson, K.-H. and Ek, J. I. (1961). Triple stem-line mosaicism in mongolism. (Letter.) Lancet, 2, 319.
Hall, B. (1963). Down's syndrome (mongolism) with a morphological Philadelphia chromosome. Lancet, 1, 558-559.

Hamerton, J. L., Jagiello, G. M., and Kirman, B. H. (1962). Sex chromosome abnormalities in a population of mentally defective children. British Medical fournal, 1, 220-223.

Hsu, L. Y.-F., Schwager, A. J., Nemhauser, I., Sobel, E. H. (1965). A case of double autosomal trisomy with mosaicism: 48/XX (trisomy $18+21$ ) and 46/XX. Fournal of Pediatrics, 66, 10551060.

Hustinx, T. W. J., Eberle, P., Geerts, S. J., ten Brink, J. and Woltring, L. M. (1961). Mongoloid twins with 48 chromosomes (AA + A21XXY). Annals of Human Genetics, 25, 111-115.

Lanman, J. T., Sklarin, B. S., Cooper, H. L., and Hirschhorn, K. (1960). Klinefelter's syndrome in a ten-month-old mongolian idiot: report of a case with chromosome analysis. New England fournal of Medicine, 263, 887-890.

Marks, J. F., Wiggins, K. M., and Spector, B. J. (1967). Trisomy 21-trisomy 18 mosaicism in a boy with clinical Down's syndrome. Fournal of Pediatrics, 71, 126-128.

Marsden, H. B., Mackay, R. I., Murray, A., and Ward, H. E. (1966). Down's syndrome with a familial $D / D$ reciprocal translocation and a G/G chromosome. Fournal of Medical Genetics, 3, 56-58.

Milcou, S. and Maicanesco, M. (1963). Syndrome de Klinefelter associé au mongolisme et à l'ectopie testiculaire bilatérale. Pathologie et Biologie, 11, 1247-1250.

Orye, E. and Delire, C. (1967). Familial $D / D$ and $D / G_{1}$ translocation. Helvetica Paediatrica Acta, 22, 36-40.

Penrose, L. S. (1967). Finger-print patterns and the sex chromosomes. Lancet, 1, 298-300.

Penrose, L. S. and Loesch, D. (1967). A study of dermal ridge width in the second (palmar) interdigital area with special reference to aneuploid states. Fournal of Mental Deficiency Research, $11,36-42$.

Penrose, L. S., and Smith, G. F. (1966). Down's Anomaly. Churchill, London.

Porter, I. H., Petersen, W., and Brown, C. D. (1969). Double autosomal trisomy (trisomy D $+\mathrm{G}$ ) with mosaicism. Fournal of Medical Genetics, 6, 347-348.

Price, W. H. and Whatmore, P. B. (1967). Criminal behaviour and the XYY male. Nature (London), 213, 815.

Punnett, H. H. and Di George, A. M. (1967). Down's/mosaicKlinefelter's syndrome. Lancet, 2, 617.

Ratcliffe, S. G., Melville, M. M., Stewart, A. L., and Jacobs, P. A. (1970). Chromosome studies on 3500 newborn male infants. Lancet, $1,121$.

Richards, B. W., Stewart, A. and Sylvester, P. E. (1965). Reciprocal translocation and mosaicism in a mongol. Fournal of Mental Deficiency Research, 9, 118-124.

Ridler, M. A. C., Pendrey, M. J., Faunch, J. A., and Berg, J. M. (1969). Association of $D / D$ translocation with mongolism fournal of Mental Deficiency Research, 13, 89-98.

Smith, G. S., Tips, R. L., and Howard, H. (1965). Autosomal mosaicism occurring in conjunction with Down's syndrome. American fournal of Mental Deficiency, 70, 218-222.

Townes, P. L. (1968). Latent aneuploidy in father and grandfather of doubly aneuploid child: mongolism in a child with 48 chromosomes. Fournal of Pediatrics, 73, 97-100.

Uchida, I. A., Ray, M., and Duncan, B. P. (1966). 21 Trisomy with an XYY sex chromosome complement. Fournal of Pediatrics, 69, 295-298.

Verresen, H. and van den Berghe, H. (1965). 21-trisomy and XYY. Lancet, 1, 609.

Welch, J. P., Borgaonkar, D. S., and Herr, H. M. (1967). Psychopathy, mental deficiency, aggressiveness and the XYY syndrome. Nature (London), 214, 500-501.

Wijck, J. A. M. van, Blankenborg, G. J., and Stolte, L. A. M. (1964). $\mathrm{XO} / \mathrm{XX}$ mosaicism and mongolism in the same person. (Letter.) Lancet, 1, 171.

Yunis, J. J., Hook, E. B. and Alter, M. (1964). XXX 21-trisomy Lancet, 1, 437-438.

Zellweger, H. and Abbo, G. (1967). Double trisomy and double trisomic mosaicism. American fournal of Diseases of Children, 113, 329-337.

Zergollern, L. and Hoefnagel, D. (1964). X-chromosome mosaicism with trisomy-21. Lancet, 1, 1108-1109.

Zergollern, L., Hoefnagel, D., Benirschke, K., and Corcoran, P. A. (1964). A patient with trisomy 21 and a reciprocal translocation in the 13-15 group. Cytogenetics, 3, 148-158. 